\title{
Defining 'natal homing' in marine fish populations: comment on Svedäng et al. (2007)
}

\author{
Ian R. Bradbury ${ }^{1, *}$, Benjamin J. Laurel $^{2}$ \\ ${ }^{1}$ Marine Gene Probe Laboratory, Biology Department, Dalhousie University, Halifax, Nova Scotia B3H 4R2, Canada \\ ${ }^{2}$ National Marine Fisheries Service, NOAA, Alaska Fisheries Science Center, Hatfield Marine Science Center, Newport, \\ Oregon 97365, USA
}

\begin{abstract}
The recent study by Svedäng et al. (2007; Mar Ecol Prog Ser 345:1-12) purports to have revealed explicit evidence of natal homing in Atlantic cod Gadus morhua, based on extensive archival tagging; the study, however, ignored the 'natal' component of dispersal (i.e. the ichthyoplanktonic phase). The authors observed non-random directional movements in a context of smallscale genetic structure. Yet, in the absence of a linkage to natal habitats, we think that the authors have inappropriately interpreted their findings. Demonstrations of natal homing remain rare in marine species, due to logistical problems, and require assignment of spawning individuals on the basis of natal signatures, or the tracking of individuals from fertilization to spawning.
\end{abstract}

KEY WORDS: Atlantic cod $\cdot$ Natal homing $\cdot$ Marine fish $\cdot$ Population structure $\cdot$ Philopatry Resale or republication not permitted without written consent of the publisher

The recent study by Svedäng et al. (2007) is receiving considerable attention in fisheries management and by population ecologists, as it purports to have revealed explicit evidence of natal homing in Atlantic cod Gadus morhua. However, the study's conclusions, based on extensive tagging of sub-adult and adult cod $(\geq 37 \mathrm{~cm})$, have ignored the 'natal' component of dispersal (i.e. egg and larval phase), the life stage in which dispersal potential may be highest (e.g. DiBacco et al. 2006). The authors have tracked cod to and from spawning grounds, a logistically difficult feat considering the population size and geographic extent in which such species travel. Similar findings by Robichaud \& Rose $(2001,2002)$ for cod on the other side of the Atlantic were equally exciting, as these studies set in place the mechanisms of small-scale connectivity and population structure. However, adult tagging alone is insufficient for establishing the existence of natal homing. As an analogy, the birthplace of a commuter cannot be assumed to be their home or place of work even though they repeatedly commute between the two. Both humans and fish potentially disperse from their natal region prior to establishing their respective regular adult migrations; thus, the regular homing region certainly does not predicate the natal region. We therefore think the authors have inappropriately interpreted their findings and may have unintentionally misled managers and scientists studying cod behavior and connectivity. We think it necessary to highlight some specific 'leaps in logic' in the manuscript and, for future studies, to lay out the pluralistic and daunting approach necessary to explicitly test 'natal homing' in a marine organism.

Measures of dispersal in marine organisms with bipartite life cycles require integrating examinations of (passive) physical transport and (active) locomotion, whose contributions are often life-stage specific. This requires the tracking of individuals from fertilization until reproduction, which is not easy to do for marine organisms. In a few species, natal homing rates may be measured via visual observation; however, such opportunities are rare and limited to marine species with large larvae and short planktonic larval durations (e.g. Davis \& Butler 1989). In the majority of species, characterized by high fecundities, small planktonic stages, and often extensive planktonic periods, visual obser- 
vation is inappropriate. In these cases, quantifying natal homing rates requires integration across the entire life history, and must encompass enough individuals to provide adequate statistical power in the face of staggeringly high mortality rates.

To date, natal homing estimates have primarily involved elemental tags (e.g. Thorrold et al. 2001, Becker et al. 2007) or molecular genetic analysis (e.g. Jones et al. 2005), either relying on habitat-specific elemental signatures (Campana \& Thorrold 2001) or assignment methods (Hauser et al. 2006), and genetic differences between individuals and populations to assign individuals among potential source locations. These studies indicate rates of natal homing often $>50 \%$ in the few species examined (authors' unpubl. data). Although the sample is biased, these data suggest that the predominance of self-recruitment and natal homing in marine species should be re-evaluated. Future examinations of marine natal homing must identify natal habitats and either track individuals until maturity and reproduction, or assign mature individuals to possible sources based on distinguishable natal tags.

Studies demonstrating high rates of multi-year spawning site fidelity suggest that early life history dispersal may be even more critical to the regulation of connectivity among marine demes. This point is illustrated in coastal Newfoundland, where Robichaud \& Rose $(2001$, 2002) document high rates of homing between years to local Atlantic cod spawning grounds. Despite homing to these spawning grounds, propagules from these same locations were exported from the coast, often dispersing over $100 \mathrm{~km}$ before hatching (Bradbury et al. 2001). Svedäng et al. (2007) argue that as cod from various localities show multidirectional movements, the impulse to home has been imprinted during early life stages. While possibly true, their evidence for 'natal' homing is circumstantial, since there is no reason to assume that any homing behavior displayed is to natal habitats. Even in the face of smallscale genetic structure in the region (e.g. Knutsen et al. 2003), mechanistic explanations are not restricted to a single option during a single life-stage. Perhaps the more parsimonious hypothesis is that individuals tagged by Svedäng et al. (2007) imprinted during the juvenile stage and homed to spawning regions on or nearby nursery areas rather than to natal locations.

The study of connectivity in marine populations will most likely continue to be a prominent area of research in marine science, as it comprises the basis for successful management of marine resources (Sale et al. 2005). A real danger lies in the potential failure to recognize biases in our measurement of marine dispersal and extrapolation across geographic areas or life history stages. The resulting spatial mismatch between scales

Editorial responsibility: Howard Browman (Associate Editorin-Chief), Storebø, Norway of metapopulation functioning and management (e.g. Laurel \& Bradbury 2006) could easily undermine conservation efforts, depleting abundance and unknown stock components (e.g. Stephenson \& Kenchington 2000). As such, the stakes are high and the attainment and interpretation of dispersal estimates remain at the cutting edge of marine science and require a careful and conservative approach.

\section{LITERATURE CITED}

Becker BJ, Levin LA, Fodrie FJ, McMillan PA (2007) Complex larval connectivity patterns among marine invertebrate populations. Proc Natl Acad Sci USA 104:3267-3272

Bradbury IR, Snelgrove PVR, Fraser S (2001) The influence of temperature on the loss of Atlantic cod (Gadus morhua) eggs and larvae from the inshore environment: a combined modeling and observational approach. Fish Oceanogr 10:342-352

Campana SE, Thorrold SR (2001) Otoliths, increments, and elements: keys to a comprehensive understanding of fish populations? Can J Fish Aquat Sci 58:30-38

Davis AR, Butler AJ (1989) Direct observations of larval dispersal in the colonial ascidian Podoclavella moluccensis Sluiter: evidence for closed populations. J Exp Mar Biol Ecol 127:189-202

DiBacco C, Levin LA, Sala E (2006) Connectivity in marine ecosystems: the importance of larval and spore dispersal. In: Crooks KR, Sanjayan M (eds) Connectivity conservation. Conservation biology, Vol 14. Cambridge University Press, Cambridge, p 184-213

Hauser L, Seamons TR, Dauer M, Naish KA, Quinn TP (2006) An empirical verification of population assignment methods by marking and parentage data: hatchery and wild steelhead (Oncorhynchus mykiss) in Forks Creek, Washington, USA. Mol Ecol 15:3157-3173

Jones GP, Planes S, Thorrold S (2005) Coral reef fish larvae settle close to home. Curr Biol 15:1314-1318

Knutsen H, Jorde PE, André C, Stenseth NC (2003) Finescaled geographic population structure in a highly mobile marine species: the Atlantic cod (Gadus morhua L.). Mol Ecol 12:385-394

Laurel BJ, Bradbury IR (2006) 'Big' concerns with high latitude marine protected areas (MPA): trends in connectivity and MPA size. Can J Fish Aquat Sci 63:2603-2607

Robichaud D, Rose GA (2001) Multiyear homing of Atlantic cod to spawning ground. Can J Fish Aquat Sci 58: 2325-2329

Robichaud D, Rose GA (2002) The return of cod transplanted from a spawning ground in southern Newfoundland. ICES J Mar Sci 59:1285-1293

Sale PF, Cowen RK, Danilowicz BS, Jones GP and 6 others (2005) Critical science gaps impede use of no-take fishery reserves. Trends Ecol Evol 20:74-80

Stephenson RL, Kenchington E (2000) Conserving fish stock structure is a critical aspect of preserving biodiversity. ICES Mini-Symposium on Defining the Role of ICES in Supporting Biodiversity Conservation. ICES CM 2000/ Mini:07

Svedäng H, Righton D, Jonsson P (2007) Migratory behaviour of Atlantic cod Gadus morhua: natal homing is the prime stock-separating mechanism. Mar Ecol Prog Ser 345:1-12

Thorrold SR, Latkoczy C, Swart PK, Jones CM (2001) Natal homing in a marine fish metapopulation. Science 291: $297-299$

Submitted: September 25, 2007; Accepted: October 18, 2007 Proofs received from author(s): October 28, 2007 